Saudi Journal of Nursing and Health Care

Abbreviated Key Title: Saudi J Nurs Health Care

ISSN 2616-7921 (Print) |ISSN 2616-6186 (Online)

Scholars Middle East Publishers, Dubai, United Arab Emirates

Journal homepage: https://scholarsmepub.com/sjnhc/

Original Research Article

\title{
Effects of Caffeine Restriction on Fetal, Neonatal and Pregnancy Outcomes
}

\author{
Amera Bekhatro Awed Allah Rashed", Neveen Adel Amer Ismail, Azza Ismail Elsayed \\ Assistant Professor, Department of Nursing, College of Applied Medical Sciences, Jouf University, Qurrayat, Female Branch, Jouf, Saudi Arabia
}

\begin{tabular}{ll}
\hline DOI: $10.36348 /$ SJNHC.2019.v02i09.003 & | Received: 29.08.2019| Accepted: 06.09.2019| Published: 20.09 .2019 \\
*Corresponding author: Amera Bekhatro Awed Allah Rashed
\end{tabular}

Abstract

Background: Caffeine is a stimulant found in tea, coffee, cola, chocolate and some over-the-counter medicines. Clearance of caffeine from the mother's blood slows down during pregnancy. Some authors of observational studies have concluded that caffeine intake is harmful to the fetus, causing growth restriction, reduced birth weight, preterm birth or still birth. The newborn could also have withdrawal symptoms if the mother has a high intake of caffeine (more than eight cups of coffee per day). Drinking three cups of coffee a day in early pregnancy had no effect on birth weight, preterm births or growth restriction. Aim of the study: The aim of this study was to assess the effects of restricting caffeine by mothers on fetal, neonatal and pregnancy outcomes. Subjects and methods: Research Design: A quasi experimental design was used in conducting this study. Sample: A purposive sample composed of 200 pregnant women. The study sample was divided randomly into 2 groups (the control and study group). Tools: Two tools were used for data collection which named; interviewing questionnaire and fetal, neonatal and pregnancy outcomes tool. Main Results: the current study revealed a relation between caffeine intake and gestational anemia, occurrence of cesarean deliveries, abnormal placental weight, neonatal low birth weight, neonatal apnea and neonatal caffeine withdrawal syndrome. Conclusion: Research hypotheses 1 is rejected while 2 and 3 are accepted. Recommendations: Preconception counseling for women about correcting the unhealthy habits including caffeine consumption. Women with previous neonatal complications must consider eliminating caffeine.

Keywords: Caffeine, Restriction, Fetal, Neonatal, Pregnancy.

Copyright @ 2019: This is an open-access article distributed under the terms of the Creative Commons Attribution license which permits unrestricted use, distribution, and reproduction in any medium for non-commercial use (NonCommercial, or CC-BY-NC) provided the original author and source are credited.

\section{INTRODUCTION}

Caffeine is the most commonly used psychoactive substance in the world. It is found in a range of beverages and food, mainly in tea, coffee, cola, chocolate bars and some medications. There has been a concern that maternal consumption of caffeine in pregnancy may be associated with adverse pregnancy outcomes. However, studies investigating antenatal caffeine intake and pregnancy outcomes have had mixed results. Some authors have concluded that caffeine intake is harmful, causing stillbirth and fetal death [1], some that it has no effect [2], and others claim that it is beneficial in reducing the risk of gestational diabetes mellitus (GDM) [3].

Caffeine, a trimethylxanthine alkaloid, is readily available in coffee (containing from 85 to 110 $\mathrm{mg} / \mathrm{cup}$ ), tea (about $50 \mathrm{mg} / \mathrm{cup}$ ), cola beverages (30 to $45 \mathrm{mg} /$ serving), cocoa (about $5 \mathrm{mg} / \mathrm{cup}$ ), chocolate (25 $\mathrm{mg} / \mathrm{small}$ bar), as well as preservatives, analgesics and other pharmaceutical preparations [4]. Caffeine's primary metabolite, paraxanthine, can pass the placental barrier, exposing the fetus to maternally ingested caffeine. Adenosine is an endogenous modulator of neuronal excitability in mammals' central nervous systems. Paraxanthine antagonises adenosine receptors (A1) in materno-fetal brain and heart inhibit glutamate release in peripheral tissues, which may have a dosedependent and cumulative adverse effect on the metabolic activity of both mother and fetus [5-7].

Animal studies have shown that chronic caffeine exposure during pregnancy promotes a decrease in adenosine A1 receptors in both maternal and fetal whole brain, which in turn increases stimulatory activities, making the brain and other tissues vulnerable to the harmful effect of caffeine because there is no blood-brain barrier or placental barrier to caffeine [8]. Moreover, clearance of caffeine from the mother's blood slows down during pregnancy and its half life is tripled during the second and third 
trimester [9], while the fetus is lacking a sufficient amount of the enzyme needed to metabolize it [10].

Maternal consumption of caffeine may possibly affect the pregnancy at any time throughout intrauterine life. Animal studies suggest that caffeine is teratogenic when administered in large amounts (more than eight cups per day), resulting in congenital anomalies, namely oral cleft and cardiovascular malformation [11-13]. However, so far, current epidemiological evidence is unable to detect appreciable teratogenic effect of caffeine exposure in the human fetus [14]. Excessive maternal caffeine consumption (more than eight cups per day)may result in increased levels of catecholamine in both the mother and fetus which may lead to utero-placental vasoconstriction [15], increased fetal heart rate and arrhythmias (irregularity of heart rate) [16] and, as a consequence, lack of fetal oxygenation. A recent study suggests caffeine impaired insulin sensitivity in women with GDM [17].

Thus, it is theoretically plausible that these effects could adversely affect the pregnancy and increase the risk of miscarriage [18], low birth weight $[19,20]$ stillbirth [21] and sudden infant death syndrome [22]. The Rondo study suggested that the proportion of mothers who delivered growth restricted babies increased as the average consumption of coffee increased [23]. Moreover, neonatal withdrawal symptoms have been observed as a result of high levels of maternal caffeine intake [24]. However, other investigators have failed to find any association between caffeine intake and poor pregnancy outcomes.

Wen [25] showed that pregnant women who were taking coffee before pregnancy had fewer incidents of spontaneous miscarriage. His populationbased prospective study was carried out on a group of 575 women who delivered singleton live births and 75 women who had spontaneous miscarriages. Clausson [26] in his prospective population-based cohort study of 953 women showed that there was no association between caffeine consumption and birth weight, gestational age and birth weight ratio. Another large prospective study of 2291 mothers also showed that caffeine consumption in the first and third trimesters was not associated with intrauterine growth restriction, low birth weight or preterm delivery [19].

Beneficial effects of caffeine intake during pregnancy are reported in some other studies. Moderate prepregnancy coffee consumption may have a protective association with GDM [3]. It has been found that the consumption of coffee increases ventilatory frequency in the general population [27]. A study on rats suggests that caffeine present in drinking fluid of lactating dams (mothers) may prevent ponto-medullary respiratory disturbances [28]. Moreover, the beneficial effect of caffeine has been shown in neonatal rodents.
Caffeine as an adenosine antagonist may prevent brain injures due to lack of oxygen.

Therefore, it is postulated that caffeine administration during early postnatal development may prevent brain injury, which is the most common cause of cerebral palsy and cognitive impairment in premature infants [29].

Conflicting results found in the literature make it difficult for health professionals to advise pregnant women about avoiding caffeine during pregnancy. The significance of this study, therefore, is to investigate the impact of avoidance of maternal consumption of caffeine on pregnancy outcome.

\section{Aim of the Study}

The aim of this study was to assess the effects of caffeine restriction by mothers on fetal, neonatal and pregnancy outcomes.

\section{Research Hypotheses}

- Mothers of the study group will have positive fetal outcomes compared to those of the control group.

- Mothers of the study group will have positive neonatal outcomes compared to those of the control group.

- Mothers of the study group will have positive pregnancy outcomes compared to those of the control group.

\section{Subject and Methods \\ Research Design}

A quasi experimental design was used in conducting this study [30].

\section{Inclusion criteria of the sample}

All recruited subjects were:

- Primigravida

- At their first trimester at the beginning of the study

- Without any pregnancy complications

- Caffeine consumers before pregnancy

\section{Study Setting}

This study was conducted at $\mathrm{MCH}$ centers and 2 private clinics at Shebin El- Koom; Menoufiya Governorate.

\section{Sample of the Study}

A purposive sample was used; the sample recruited in this study consisted of 200 pregnant women. The study sample was divided randomly into 2 groups (the control and study group). The study group: participants who were instructed to prevent caffeine intake during their gestational period. Control group: participants who keep their regular daily caffeine intake. 


\section{Data Collection Tools}

Throughout the course of the present study; data were collected using two tools which were developed by the researchers and revised by a jury of qualified experts, then tested for validity and reliability. Tools were: interviewing questionnaire and fetal, neonatal and pregnancy outcomes tool.

- Interviewing questionnaire: it consisted of closed ended questions about age, history of chronic diseases, menstrual history (e.g, age of menarche, menstrual regularity,.....), data about present pregnancy (e.g, LMP, EDD, fetal condition, ......).

- Fetal, neonatal and pregnancy outcomes tool: it consists of three parts including data about: part 1 fetal outcomes like: birth weight $(\mathrm{g})$ : low birth weight (a fetus that weighs less than $2500 \mathrm{~g}$ ), regardless of gestational age (assessed at time of birth), very low birth weight which is less than $1500 \mathrm{~g}$, and extremely low birth weight, which is less than $1000 \mathrm{~g}$. Small-forgestational age (those whose birth weight lies below the 10th percentile for that gestational age, assessed at time of birth). First trimester fetal loss or miscarriage. Stillbirth (delivery of a dead fetus at 28 weeks' gestation or more). Fetal hypoxia. Preterm birth (i.e. the birth of a baby before 37 weeks). Post-term birth (i.e. the birth of a baby after 40 weeks). Part 2 Neonatal outcomes like: neonatal caffeine withdrawal syndrome, neonatal apnoea, tachycardia and arrhythmias, sudden infant death syndrome (a syndrome marked by the symptoms of sudden and unexplained death of an apparently healthy infant). Part 3 Pregnancy outcomes like: mode of delivery, pregnancy complication including: anemia, hyperemesis gravidarum, gestational diabetes, preterm labor, premature rupture of membrane, pregnancy induced hypertension, intrauterine growth restriction, intrauterine fetal death.

\section{Validity of the Data Collection Tools}

The validity of the tools was ascertained by a group of subject area experts who reviewed the tools for content and internal validity. They were also asked to judge the items for completeness and clarity. Suggestions were incorporated into the tools.

\section{Reliability of the Data Collection Tools}

Test - retest reliability was applied by the researcher for testing the internal consistency of the tool. It was done through the administration of the same tools to the same participants under similar conditions on two or more occasions. Scores from repeated testing were compared.

\section{Ethical Consideration}

Approaches to ensure ethics were considered in the study regarding confidentiality and the informed consent. Confidentiality was achieved by the use of locked sheets with the names of women replaced by numbers. All women were informed that the information they provided during the study would be kept confidential and used only for statistical purpose and after finishing the study, the findings would be presented as a group data with no personal women's information remained.

\section{Pilot Study}

Piloting was conducted to test the applicability of the tools, the feasibility of the study and to estimate the time needed for data collection. It was conducted on $10 \%$ of the total sample (20 women). On the basis of the pilot study results; the researcher rephrased some questions and sentences then set the final fieldwork schedule.

\section{Data Analysis}

Upon completion of data collection, each answer sheet was revised, coded and scored. The researcher coded the data into a coding sheet so that data could be prepared for computer use. Data was statistically analyzed using statistical package for social science (SPSS. IBM, USA, 2012) version 20 on IBM compatible computer. Test of significance was used and level of significance was at $\mathrm{p}<0.05$ [36].

The following statistical techniques were used: frequencies and percentage, Chi square, Spearman's rho coefficient and correlation analysis.

\section{Frequencies and percentage distribution}

Was done to sociodemographic data of participants.

The Chi-square test $\left(\chi^{2}\right)$ was used for comparing frequencies or proportions. The test is also referred to as a test of a measure of fit or "goodness of fit" between data.

$$
\left(\chi^{2}\right)=\frac{(\mathbf{O}-\mathbf{E})^{2}}{\mathbf{E}}
$$

Where:

$$
\begin{aligned}
& \mathrm{O}=\text { observed frequency } \\
& \mathrm{E}=\text { Expected frequency }
\end{aligned}
$$

T- Test to compare mean scores it was used to test the difference between two means.

\section{Significance of Results}

For all the statistical tests done, the threshold of significance is fixed at the 5\% level ( $\mathrm{P}$ value), as follows:

Non - significant difference if $\quad \mathrm{P}>$

Significant difference if $\quad \mathrm{P}<$ 
0.001

Highly significant difference if $\quad \mathrm{P}<$

Procedure and Maneuver of Intervention

The current study was carried out in two consecutive phases, namely preparatory and implementation or data collection phases.

\section{The Preparatory Phase}

An extensive review related to the study area was done including electronic dissertations, available books, articles and periodicals. A review of literature to formulate knowledge base relevant to the study area was also done. An official permission was granted from the centers and clinics authorities.

\section{The Implementation or data collection phase}

The researchers applied this phase in the following steps:

The $1^{\text {st }}$ step: After determining the sample of the study, the researchers introduced themselves to the pregnant women and provided verbal explanation of the study, answered all related questions, and provided a study packet to each woman. The study packet included a written overview of the study including main sources of caffeine and information detailing how to contact with the researchers for questions or additional information. Women's telephone number and e-mails (if available) were taken to facilitate communication and follow up.

The $2^{\text {nd }}$ step: The researchers met each woman in her next antenatal visit and the interviewing questionnaire was used for collecting data. The study group was informed about caffeine sources and instructed to restrict the intake along the gestational period.

The $3^{\text {rd }}$ step: Weekly and by telephone, researchers followed-up each group to ensure caffeine restriction (by the control group) and regular caffeine consumption (by the control group).

The $4^{\text {th }}$ step: At the $3^{\text {rd }}$ trimester and near term; the researchers completed part I and part 3 from the $2^{\text {nd }}$ data collection tool (fetal outcome and pregnancy outcomes).

The $5^{\text {th }}$ step: At delivery; the researchers completed part 3 from the $2^{\text {nd }}$ data collection tool (neonatal outcomes) then followed-up the infant condition for one month by telephone for detecting sudden infant death syndrome and neonatal caffeine withdrawal syndrome.

\section{RESULTS}

Table-1: Sociodemographic Characteristics of the Sample

\begin{tabular}{|c|c|c|c|c|c|c|}
\hline \multirow[t]{2}{*}{ Variable } & \multicolumn{2}{|c|}{$\begin{array}{l}\text { Study group } \\
(\mathbf{n}=\mathbf{1 0 0})\end{array}$} & \multicolumn{2}{|c|}{$\begin{array}{l}\text { Control group } \\
(\mathbf{n = 1 0 0 )}\end{array}$} & \multirow[t]{2}{*}{ Test } & \multirow[t]{2}{*}{ P-value } \\
\hline & No & $\%$ & No & $\%$ & & \\
\hline Age & & & & & \multirow{2}{*}{$\begin{array}{l}\mathbf{t} \\
0.1\end{array}$} & \multirow[t]{2}{*}{$>0.05$} \\
\hline Mean \pm SD & \multicolumn{2}{|c|}{$25.09 \pm 1.56$} & \multicolumn{2}{|c|}{$25.01 \pm 2.50$} & & \\
\hline \multicolumn{5}{|l|}{ Level of education } & \multirow{5}{*}{$\begin{array}{l}\chi^{2} \\
0.2\end{array}$} & \multirow{5}{*}{$>0.05$} \\
\hline Illiterate & - & - & - & - & & \\
\hline Basic & 2 & 2 & - & - & & \\
\hline Secondary & 45 & 45 & 41 & 41 & & \\
\hline University & 53 & 53 & 59 & 59 & & \\
\hline \multicolumn{5}{|l|}{ Residence } & \multirow{3}{*}{$\begin{array}{l}\chi^{2} \\
1.1\end{array}$} & \multirow[t]{3}{*}{$>0.05$} \\
\hline Urban & 15 & 15 & 10 & 10 & & \\
\hline Rural & 85 & 85 & 90 & 90 & & \\
\hline \multicolumn{5}{|l|}{ Accommodation } & \multirow{3}{*}{$\begin{array}{c}\chi^{2} \\
5.0\end{array}$} & \multirow[t]{3}{*}{$>0.05$} \\
\hline With husband family & 13 & 13 & 9 & 9 & & \\
\hline Alone & 87 & 87 & 91 & 91 & & \\
\hline \multicolumn{5}{|l|}{ Monthly income } & \multirow{3}{*}{$\begin{array}{l}\chi^{2} \\
0.1\end{array}$} & \multirow[t]{3}{*}{$>0.05$} \\
\hline Enough & 17 & 17 & 15 & 15 & & \\
\hline Not-enough & 83 & 83 & 85 & 85 & & \\
\hline
\end{tabular}

Table-1 displays the sociodemographic characteristics of the studied sample. It shows that the majority of the sample in both groups was rural residents, and was living alone (away from their husbands' family). There was no statistically significant difference between groups regarding any one of the sociodemographic characteristics. 
Table-2: Distribution of the Sample regarding their History of Current Pregnancy

\begin{tabular}{|c|c|c|c|c|c|c|}
\hline \multirow[t]{2}{*}{ Variable } & \multicolumn{2}{|c|}{$\begin{array}{l}\text { Study group } \\
(\mathbf{n}=\mathbf{1 0 0})\end{array}$} & \multicolumn{2}{|c|}{$\begin{array}{l}\text { Control group } \\
(\mathbf{n}=\mathbf{1 0 0})\end{array}$} & \multirow[t]{2}{*}{$\begin{array}{l}\chi^{2} \\
\text { Test }\end{array}$} & \multirow[t]{2}{*}{ P-value } \\
\hline & No & $\%$ & No & $\%$ & & \\
\hline \multicolumn{5}{|l|}{ Gestational age at the start of the study } & \multirow[t]{4}{*}{0.0} & \multirow[t]{4}{*}{$>0.05$} \\
\hline $1^{\mathrm{st}}$ & 100 & 100 & 100 & 100 & & \\
\hline $2^{\text {nd }}$ & 0 & 0 & 0 & 0 & & \\
\hline $3^{\text {rd }}$ & 0 & 0 & 0 & 0 & & \\
\hline \multicolumn{5}{|l|}{ Pregnancy complications at the start of the study } & \multirow[t]{3}{*}{0.0} & \multirow[t]{3}{*}{$>0.05$} \\
\hline Yes & 0 & 0 & 0 & 0 & & \\
\hline No & 100 & 100 & 100 & 100 & & \\
\hline \multicolumn{5}{|l|}{ Follow-up } & \multirow[t]{3}{*}{2.7} & \multirow[t]{3}{*}{$>0.05$} \\
\hline $\mathrm{MCH}$ & 95 & & 91 & & & \\
\hline Private Clinic & 5 & & 9 & & & \\
\hline
\end{tabular}

Table-2 presents the history of current pregnancy; the table reflects the inclusion criteria of the sample. It is noticed that all women were at their first

trimester of pregnancy and were free from any complications; they were also following-up their pregnancy at the $\mathrm{MCH}$ center.

Table-3: Distribution of the control group regarding sources and the average daily caffeine intake

\begin{tabular}{|c|c|c|c|}
\hline Variable & $\begin{array}{l}\text { Control group } \\
(\mathbf{n}=\mathbf{1 0 0})\end{array}$ & Unit & $\begin{array}{l}\text { Caffeine per } \\
\text { unit, } \mathrm{Mg}\end{array}$ \\
\hline \multicolumn{4}{|l|}{ Sources of caffeine } \\
\hline \multicolumn{4}{|l|}{ Coffee } \\
\hline $\begin{array}{l}\text { Brewed } \\
0 \\
1-2 \\
3-4\end{array}$ & $100 \%$ & $237 \mathrm{~mL}(1 \mathrm{cup}, 8 \mathrm{oz})$ & 135 \\
\hline $\begin{array}{l}\text { Instant } \\
0 \\
1-2 \\
3-4\end{array}$ & $\begin{array}{l}20 \% \\
59 \% \\
21 \%\end{array}$ & $237 \mathrm{~mL}$ (1 cup, 8 oz) & $76-106$ \\
\hline \multicolumn{4}{|l|}{ Tea } \\
\hline $\begin{array}{l}\text { Instant } \\
0 \\
1-2 \\
3-4 \\
\end{array}$ & $\begin{array}{l}7 \% \\
33 \% \\
60 \% \\
\end{array}$ & $237 \mathrm{~mL}$ (1 cup, $8 \mathrm{oz})$ & 30 \\
\hline $\begin{array}{l}\text { Green } \\
0 \\
1-2 \\
3-4\end{array}$ & $100 \%$ & $237 \mathrm{~mL}$ (1 cup, 8 oz) & 15 \\
\hline \multicolumn{4}{|l|}{ Soft drinks } \\
\hline $\begin{array}{l}\text { Cola } \\
0 \\
1-2 \\
3-4 \\
\end{array}$ & $\begin{array}{l}16 \% \\
83 \% \\
1 \% \\
\end{array}$ & $355 \mathrm{~mL}(1 \mathrm{can}, 12 \mathrm{oz})$ & $36-46$ \\
\hline $\begin{array}{l}\text { Diet cola } \\
0 \\
1-2 \\
3-4\end{array}$ & $100 \%$ & $355 \mathrm{~mL}(1 \mathrm{can}, 12 \mathrm{oz})$ & $39-50$ \\
\hline \multicolumn{4}{|l|}{ Cacao products } \\
\hline $\begin{array}{l}\text { Candy (milk chocolate) } \\
0 \\
1-2 \\
3-4\end{array}$ & $\begin{array}{l}71 \% \\
29 \% \\
0 \% \\
\end{array}$ & $28 \mathrm{~g}(1 \mathrm{oz})$ & 7 \\
\hline $\begin{array}{l}\text { Hot cocoa mix } \\
0 \\
1-2 \\
3-4\end{array}$ & $100 \%$ & $237 \mathrm{~mL}$ (1 envelope, $8 \mathrm{oz}$ ) & 5 \\
\hline
\end{tabular}


Amount of caffeine per unit is calculated according to: Food and nutrition. Caffeine in foods. Ottawa, ON: Health Canada; 2012.
Table-3 discusses the main intervention of the study. The table shows that the study group was restricting caffeine intake along the study period.

Table-4: Distribution of the Sample regarding their Pregnancy Outcomes

\begin{tabular}{|c|c|c|c|c|c|c|}
\hline \multirow[t]{2}{*}{ Variable } & \multicolumn{2}{|c|}{$\begin{array}{l}\text { Study group } \\
(\mathbf{n}=\mathbf{1 0 0})\end{array}$} & \multicolumn{2}{|c|}{$\begin{array}{l}\text { Control group } \\
(\mathbf{n}=\mathbf{1 0 0})\end{array}$} & \multirow[t]{2}{*}{$\begin{array}{l}\chi^{2} \\
\text { Test }\end{array}$} & \multirow[t]{2}{*}{ P-value } \\
\hline & No & $\%$ & No & $\%$ & & \\
\hline Length of gestation & & & & & 1.2 & $>0.05$ \\
\hline Full term pregnancy & 98 & 98 & 97 & 97 & & \\
\hline Preterm delivery & 2 & 2 & 3 & 3 & & \\
\hline \multicolumn{7}{|c|}{ Pregnancy complication (by the end of gestational period) } \\
\hline Anemia & & & & & 14.4 & $<0.001 *$ \\
\hline Yes & 27 & 27 & 54 & 54 & & \\
\hline No & 73 & 73 & 46 & 46 & & \\
\hline Hyperemesis gravidarum & & & & & 0.2 & $>0.05$ \\
\hline 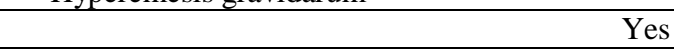 & 0 & 0 & 1 & 1 & & \\
\hline No & 100 & 100 & 99 & 99 & & \\
\hline Gestational diabetes & & & & & 0.4 & $>0.05$ \\
\hline Yes & 1 & 1 & 3 & 3 & & \\
\hline No & 99 & 99 & 97 & 97 & & \\
\hline Pregnancy induced hypertension & & & & & 2.3 & $>0.05$ \\
\hline 1 & 3 & 3 & 9 & 9 & & \\
\hline No & 97 & 97 & 91 & 91 & & \\
\hline Intrauterine growth restriction & & & & & 0.0 & $>0.05$ \\
\hline Yes & 0 & 0 & 0 & 0 & & \\
\hline No & 100 & 100 & 100 & 100 & & \\
\hline Intrauterine fetal death & & & & & 0.4 & $>0.05$ \\
\hline Yes & 0 & 0 & 1 & 1 & & \\
\hline No & 100 & 100 & 99 & 99 & & \\
\hline Premature rupture of membrane & & & & & 3.2 & $>0.05$ \\
\hline Yes & 1 & 1 & 5 & 5 & & \\
\hline No & 99 & 99 & 95 & 95 & & \\
\hline \multicolumn{7}{|l|}{ Type of delivery } \\
\hline Normal labor & 25 & 25 & 15 & 15 & 11.4 & $<0.001 *$ \\
\hline Cesarean section & 75 & 75 & 85 & 85 & 12.1 & $<0.001^{*}$ \\
\hline
\end{tabular}

(*) Statistically significant at $\mathrm{p}<0.001$

Table-4 shows one of the main study results; which is the pregnancy outcomes. The table displays that there was a highly statistically significant difference between groups regarding occurrence of anemia and rate of cesarean section. From noticing this table; hypothesis 3 is accepted "Mothers of the study group will have positive pregnancy outcomes compared to those of the control group".

Table-5: Distribution of the Sample regarding their Fetal Outcomes

\begin{tabular}{|c|l|l|l|l|l|l|}
\hline \multirow{2}{*}{ Variable } & \multicolumn{2}{|l|}{$\begin{array}{l}\text { Study group } \\
(\mathbf{n = 1 0 0})\end{array}$} & \multicolumn{2}{l}{$\begin{array}{l}\text { Control group } \\
(\mathbf{n = 1 0 0})\end{array}$} & $\begin{array}{l}\boldsymbol{\chi}^{\mathbf{2}} \\
\text { Test }\end{array}$ & \multirow{2}{*}{ P-value } \\
\cline { 2 - 6 } & No & $\mathbf{\%}$ & No & $\mathbf{\%}$ & & \\
\hline $\mathbf{1}^{\text {st }}$ trimester fetal loss & & & & & 2.9 & $>0.05$ \\
\hline Yes & 7 & 7 & 12 & 12 & & \\
\hline No & 93 & 93 & 88 & 88 & & \\
\hline Fetal hypoxia & & & & & 2.2 & $>0.05$ \\
\hline Yes & 2 & 2 & 9 & 9 & & \\
\hline No & 98 & 98 & 91 & 91 & & \\
\hline Pre-term birth & & & & & 1.8 & $>0.05$ \\
\hline Yes & 2 & 2 & 7 & 7 & & \\
\hline No & 98 & 98 & 93 & 93 & & \\
\hline Post-term birth & & & & & & $>0.05$ \\
\hline Yes & 0 & 0 & 0 & 0 & 0.0 & \\
\hline No & 100 & 100 & 100 & 100 & & \\
\hline Still birth & & & & & & $>0.05$ \\
\hline Yes & 0 & 0 & 0 & 0 & 0.0 & \\
\hline No & 100 & 100 & 100 & 100 & & \\
\hline
\end{tabular}

(*) Statistically significant at $\mathrm{p}<0.001$ 
Table-5 shows another one of the main study results; which is the fetal outcomes. The table displays that there was no statistically significant difference between groups regarding birth weight. Hypothesis 1 is thus rejected "Mothers of the study group will have positive fetal outcomes compared to those of the control group".

Table-6: Distribution of the Sample regarding their Neonatal Outcomes

\begin{tabular}{|c|c|c|c|c|c|c|}
\hline \multirow[t]{2}{*}{ Variable } & \multicolumn{2}{|c|}{$\begin{array}{l}\text { Study group } \\
(\mathbf{n}=\mathbf{1 0 0})\end{array}$} & \multicolumn{2}{|c|}{$\begin{array}{l}\text { Control group } \\
(\mathbf{n}=\mathbf{1 0 0})\end{array}$} & \multirow[t]{2}{*}{$\begin{array}{l}\chi^{2} \\
\text { Test }\end{array}$} & \multirow[t]{2}{*}{ P-value } \\
\hline & No & $\%$ & No & $\%$ & & \\
\hline \multicolumn{5}{|l|}{ Placental weight } & \multirow[t]{4}{*}{13.4} & \multirow[t]{4}{*}{$<0.001 *$} \\
\hline Normal & 94 & 94 & 80 & 80 & & \\
\hline Less than normal & 3 & 3 & 18 & 18 & & \\
\hline More than normal & 3 & 3 & 2 & 2 & & \\
\hline \multicolumn{5}{|l|}{ Neonatal Bbirth weight } & \multirow[t]{3}{*}{12.2} & \multirow[t]{3}{*}{$<0.001^{*}$} \\
\hline Low & 1 & 1 & 12 & 12 & & \\
\hline Small for gestational age & 1 & 1 & 3 & 3 & & \\
\hline \multicolumn{5}{|l|}{ Length of fetus } & & \\
\hline $40-50 \mathrm{~cm}$ & 100 & 100 & 100 & 100 & & \\
\hline \multicolumn{5}{|l|}{ Neonatal caffeine withdrawal syndrome } & \multirow[t]{3}{*}{17.3} & \multirow[t]{3}{*}{$<0.001^{*}$} \\
\hline Yes & 0 & 0 & 92 & 92 & & \\
\hline No & 100 & 100 & 8 & 8 & & \\
\hline Neonatal apnea & & & & & 11.0 & $<0.001 *$ \\
\hline Yes & 3 & 3 & 12 & 12 & & \\
\hline No & 97 & 97 & 88 & 88 & & \\
\hline Tachycardia \& arrhythmias & & & & & 0.4 & $>0.05$ \\
\hline Yes & 1 & 1 & 2 & 2 & & \\
\hline No & 99 & 99 & 98 & 98 & & \\
\hline Sudden infant death syndrome & & & & & 0.0 & $>0.05$ \\
\hline Yes & 0 & 0 & 0 & 0 & & \\
\hline No & 100 & 100 & 100 & 100 & & \\
\hline
\end{tabular}

(*) Statistically significant at $\mathrm{p}<0.001$

Table-6 shows the fetal outcomes of the studied sample as a main result of the study. The table displays that there was a highly statistically significant difference between groups regarding neonatal caffeine withdrawal syndrome and neonatal apnea. Hypothesis 2 is accepted "Mothers of the study group will have positive neonatal outcomes compared to those of the control group".

\section{DISCUSSION}

The current study tried to evaluate the effect of caffeine restriction on pregnancy, fetal and neonatal outcomes. From reviewing literature; there is insufficient evidence to evaluate the effect of caffeine on fetal, neonatal and pregnancy outcomes. The current study showed an association between caffeine intake and pregnancy complications like anemia and outcomes like type of delivery. Some observational studies with cohort study designs and large sample sizes failed to show any association between caffeine intake and poor pregnancy outcomes $[19,26]$. Comparative observational studies suggest that caffeine can have a debilitating effect on the natural growth of the fetus, leading to intrauterine growth restriction (IUGR) [23]. The current study findings showed no association between caffeine intake and occurrence of IUGR as one of pregnancy outcomes.

Current findings of fetal outcomes showed no effect of caffeine on the fetus. On contrast Justin C Konje [31] in a large prospective observational study named "Maternal caffeine intake during pregnancy and risk of fetal growth restriction" reported certain fetal complication linked to caffeine intake. He found that average caffeine consumption of $>100 \mathrm{mg} /$ day was associated with a reduction in weight of 34-59 $\mathrm{g}$ in the first trimester, 24-74 $\mathrm{g}$ in the second, and 66-89 $\mathrm{g}$ in the third (after adjustment for smoking status and alcohol intake). Similar results were seen by Bracken et al., [32] in a prospective study of 2291 pregnant women in the US, where mean fetal weight was reduced by $28 \mathrm{~g}$ for every $100 \mathrm{mg} /$ day of caffeine consumed. In contrast to the current findings; Wisborg [21] who reported that caffeine can result in stillbirth. This difference could be explained by methodological differences in the studies.

The current study showed a decrease in neonatal weight among control group which is linked to caffeine consumption. At the same line a combined analyses of mean birth weigh study results as summarized in a detailed meta-analysis by Iná S. Santos 
et al., [33] showed a significant decrease in birth weight of nearly $43 \mathrm{~g}$ among newborns of the heaviest caffeineconsuming mothers. Comparative observational studies also suggest that caffeine can lead to low birth weight [19].

On contrast, a Danish cohort of 1207 women drinking at least three cups of coffee a day before 20 weeks of pregnancy were randomized to receive either caffeinated or decaffeinated instant coffee: there was no significant difference in birth weight between the two groups after adjustment for parity, gestational age at birth, and smoking [34]. However, these women were recruited in the second half of pregnancy, so the effect of first trimester caffeine intake was not assessed, and there was no biochemical confirmation of participants' compliance with caffeinated or decaffeinated coffee consumption.

In addition, Bicalho and Filho [35] reported no association between maternal caffeine consumption and low birth weight after adjusting for confounding variables in a case-control study in Brazil.

The present study assessed placental weight, neonatal caffeine withdrawal syndrome and neonatal apnea as variables of neonatal outcomes and a statistically significant difference between groups was observed. Form reviewing literature; no studies examined caffeine effect on neonatal outcomes had tested those items.

\section{CONCLUSION}

In the light of the current study findings, it can be concluded that research hypotheses 1 is rejected while 2 and 3 are accepted:

Research hypothesis 1 Mothers of the study group will have positive fetal outcomes compared to those of the control group. The study findings revealed no difference between groups regarding fetal outcomes items.

Research hypothesis 2 Mothers of the study group will have positive neonatal outcomes compared to those of the control group.

Research hypothesis 3 Mothers of the study group will have positive pregnancy outcomes compared to those of the control group.

\section{RECOMMENDATIONS}

In the light of the foregoing study results, the following recommendations are proposed: Preconception counseling for women about correcting the unhealthy habits including caffeine consumption.

Women with previous neonatal complications must consider eliminating caffeine containing beverages from their diet during gestation.
Women who are caffeine consumers can gradually substitute their regular beverages with noncaffeinated ones that taste just like regular beverages.

This area of research needs additional efforts in order to expand the evidence base on the association between caffeine and fetal, neonatal and pregnancy outcomes.

\section{REFERENCES}

1. Bech, M., \& Gyrd-Hansen, D. (2005). Effects coding in discrete choice experiments. Health economics, 14(10), 1079-1083.

2. Browne, M. N., \& Keeley, S. M. (2007). Asking the right questions: A guide to critical thinking. Pearson Education.

3. Adeney, K. (2007). Comment: The "Necessity" of Asymmetrical Federalism?. Ethnopolitics, 6(1), 117-120.

4. Knutti, R., \& Schlatter, C. (1982). Distribution of aflatoxin in whole peanut kernels, sampling plans for small samples. Zeitschrift für LebensmittelUntersuchung und Forschung, 174(2), 122-128.

5. Gaytan, J. (2009). Analyzing online education through the lens of institutional theory and practice: The need for research-based andvalidated frameworks for planning, designing, delivering, and assessing online instruction. Delta Pi Epsilon Journal, 51(2).

6. Bicego, M., Lagorio, A., Grosso, E., \& Tistarelli, M. (2006, June). On the use of SIFT features for face authentication. In 2006 Conference on Computer Vision and Pattern Recognition Workshop (CVPRW'06) (pp. 35-35). IEEE.

7. Sánchez-Iglesias, A., Pastoriza-Santos, I., PérezJuste, J., Rodríguez-González, B., Garcia de Abajo, F. J., \& Liz-Marzán, L. M. (2006). Synthesis and optical properties of gold nanodecahedra with size control. Advanced Materials, 18(19), 2529-2534.

8. Lasdon, L. S. (2002). Optimization theory for large systems. Courier Corporation.

9. Knutti, R., Rothweiler, H., \& Schlatter, C. (1981). Effect of pregnancy on the pharmacokinetics of caffeine. European journal of clinical pharmacology, 21(2), 121-126.

10. Aldridge, A., Aranda, J. V., \& Neims, A. H. (1979). Caffeine metabolism in the newborn. Clinical Pharmacology \& Therapeutics, 25(4), 447-453.

11. Berger, A. (1988). Milankovitch theory and climate. Reviews of geophysics, 26(4), 624-657.

12. Bruyere Jr, H. J., Michaud, B. J., Gilbert, E. F., \& Folts, J. D. (1987). The effects of cardioteratogenic doses of caffeine on cardiac function in the 3-day chick embryo. Journal of applied toxicology, 7(3), 197-203.

13. Elmazar, M. M. A., McElhatton, P. R., \& Sullivan, F. M. (1982). Studies on the teratogenic effects of different oral preparations of caffeine in 
mice. Toxicology, 23(1), 57-71.

14. Browne, M. O., Wells, J. E., \& Scott, K. M. (2006). Te rau hinengaro: The New Zealand mental health survey. Wellington: Ministry of Health, 151-2.

15. Kirkinen, P., Jouppila, P., Koivula, A., Vuori, J., \& Puukka, M. (1983). The effect of caffeine on placental and fetal blood flow in human pregnancy. American Journal of Obstetrics \& Gynecology, 147(8), 939-942.

16. Resch, C. M., \& Gibson, J. A. N. E. (1983). Isolation of the carotenoid-containing cell wall of three unicellular cyanobacteria. Journal of bacteriology, 155(1), 345-350.

17. Robinson, W. S. (2009). Ecological correlations and the behavior of individuals. International journal of epidemiology, 38(2), 337-341.

18. Tolstrup, K., \& Smedegaard-Petersen, V. (1984). Saprophytic leaf fungi on barley and their effect on leaf senescence and grain yield. Växtskyddsnotiser, 48, 66-75.

19. Bracken, M. B., Triche, E. W., Belanger, K., Saftlas, A., Beckett, W. S., \& Leaderer, B. P. (2003). Asthma symptoms, severity, and drug therapy: a prospective study of effects on 2205 pregnancies. Obstetrics \& Gynecology, 102(4), 739-752.

20. Klebanoff, M. A., Levine, R. J., Clemens, J. D., \& Wilkins, D. G. (2002). Maternal serum caffeine metabolites and small-for-gestational age birth. American journal of epidemiology, 155(1), 32-37.

21. Kesmodel, U., Wisborg, K., Olsen, S. F., Henriksen, T. B., \& Secher, N. J. (2002). Moderate alcohol intake during pregnancy and the risk of stillbirth and death in the first year of life. American journal of epidemiology, 155(4), 305-312.

22. Ford, L. K. (1988). Origins of Southern Radicalism: The South Carolina Upcountry, 18001860. Oxford University Press.

23. Rondo, P. H., Rodrigues, L. C., \& Tomkins, A. M. (1996). Coffee consumption and intrauterine growth retardation in Brazil. European journal of clinical nutrition, 50(11), 705-709.

24. McGowan, R. S. (1988). An aeroacoustic approach to phonation. The Journal of the Acoustical Society of America, 83(2), 696-704.

25. Tan, R. X., \& Zou, W. X. (2001). Endophytes: a rich source of functional metabolites. Natural product reports, 18(4), 448-459.
26. Clausson, B., Granath, F., Ekbom, A., Lundgren, S., Nordmark, A., Signorello, L. B., \& Cnattingius, S. (2002). Effect of caffeine exposure during pregnancy on birth weight and gestational age. American Journal of Epidemiology, 155(5), 429-436.

27. Martinet, W., Knaapen, M. W., De Meyer, G. R., Herman, A. G., \& Kockx, M. M. (2002). Elevated levels of oxidative DNA damage and DNA repair enzymes in human atherosclerotic plaques. Circulation, 106(8), 927-932.

28. Bodineau, T., \& Derrida, B. (2006). Current large deviations for asymmetric exclusion processes with open boundaries. Journal of statistical physics, 123(2), 277-300.

29. Back, S. A. (2006). Perinatal white matter injury: the changing spectrum of pathology and emerging insights into pathogenetic mechanisms. Mental retardation and developmental disabilities research reviews, 12(2), 129-140.

30. Polit, D. F., Widom, R., Edin, K., Bowie, S., London, A. S., Scott, E. K., \& Valenzuela, A. (2001). Is Work Enough? The Experiences of Current and Former Welfare Mothers Who Work.

31. Lam, P. M., Marczylo, T. H., El-Talatini, M., Finney, M., Nallendran, V., Taylor, A. H., \& Konje, J. C. (2008). Ultra performance liquid chromatography tandem mass spectrometry method for the measurement of anandamide in human plasma. Analytical biochemistry, 380(2), 195-201.

32. Bracken, P. (2002). Trauma: Culture, meaning and philosophy. Whurr Publishers.

33. Santos, I. S., Victora, C. G., Huttly, S., \& Carvalhal, J. B. (1998). Caffeine intake and low birth weight: a population-based case-control study. American Journal of Epidemiology, 147(7), 620-627.

34. Bech, B. H., Obel, C., Henriksen, T. B., \& Olsen, J. (2007). Effect of reducing caffeine intake on birth weight and length of gestation: randomised controlled trial. bmj, 334(7590), 409.

35. Bicalho, G. G., \& Barros Filho, A. D. A. (2002). Birthweight and caffeine consumption. Revista de saude publica, 36(2), 180-187.

36. Fisher, A. (2008). M1 muscarinic agonists target major hallmarks of Alzheimer's disease-the pivotal role of brain M1 receptors. Neurodegenerative Diseases, 5(3-4), 237-240. 